\title{
MARINE INDUSTRIAL CLUSTER STRUCTURE AND ITS COUPLING RELATIONSHIP WITH URBAN DEVELOPMENT: A CASE OF SHANDONG PROVINCE
}

\author{
Xiao Wenwen \\ Zhao Bingxin \\ Wang Lili \\ School of Management, Shandong University, Jinan, Shandong, 250100, China
}

\begin{abstract}
Marine economy is a new economic form, emphasizing new development concept, new operation mechanism and management mode. In recent years, marine economy shows rapid growth, and marine industry presents a clustering development trend. The industrial linkage effect, industrial agglomeration effect and industrial radiation effect of the marine industrial cluster are important motive forces for the development of coastal cities. The marine industrial cluster takes coastal cities as the development platform and space, while the coastal cities achieve rapid and sustainable development based on the marine industrial cluster. The synergetic and coupling development of the marine industrial cluster and coastal cities is an important way for the promotion of industrial competitiveness and urban competitiveness. This paper developed a measure to identify the marine industrial cluster, designed the evaluation index of coupling of marine industrial cluster and coastal cities development from two perspectives of industrial linkage and spatial agglomeration, taking Shandong province, a typical coastal province in China, as an example, it studied the situation of the marine industrial cluster based on input-output data and data of marine enterprises of coastal cities, based on which it explored the coupling relationship between marine industrial cluster and coastal cities of Shandong province.
\end{abstract}

Keywords: marine industry; industrial cluster; urban development; coupling coordination model

\section{INTRODUCTION}

With the increase of human social and economic activity, the supporting capacity of land resource has been overwhelmed, so people need to find new resource supporting point [1]. In this background, economic activity presents an extension from the land to the ocean, which includes both the extension of the land resource to the marine resource and the extension of economic activities from the land space to the ocean space. At the start of this century, the United Nation proposed the assertion of "The 21st century is ocean century", believing the ocean will become the main area of international competition [2]. Marine economy is a new economic form with synergy of sea and land and sustainable development as the core concepts, emphasizing new development concept, new operation mechanism and management mode $[3,4]$.With the implementation of marine strategy, marine economy shows rapid growth, and marine industry presents a clustering development trend [5]. The industrial linkage effect, industrial agglomeration effect and industrial radiation effect of the marine industrial cluster are important motive forces for the development of coastal cities, and also bases for connection among coastal cities. The marine industrial cluster has become an important factor in explaining competitiveness, innovation and growth of coastal cities $[6,7,8]$.The marine industrial cluster takes coastal cities as the development platform and space, while coastal cities achieve rapid and sustainable development based on the marine industrial cluster. The synergetic and 
coupling development of the marine industrial cluster and coastal cities is an important way for the promotion of industrial competitiveness and urban competitiveness.

The industrial cluster is first proposed by Michael Porter, who defined cluster as a geographically proximate group of interconnected companies and associated institutions in a particular field, linked by commonalities and complementarities [9]. Thus it can be seen that the important external expression of the industrial cluster is geographical agglomeration of relevant enterprises and institutions. Subsequently, scholars pointed out that the formation of industrial cluster is not only because of proximity of geographical position, but also existence of industrial linkage $[10,11]$, besides, some scholars proposed the way to identify industrial cluster from two perspectives of horizontal industrial linkage and vertical industrial linkage to study German industrial cluster [12]. Based on these theories, this paper argued that two conditions needed to be satisfied for the formation of industrial cluster: firstly, there was an existence of linkage among industries; secondly, enterprises and institutions formed a certain agglomeration scale in terms of geographical position. From the point of view of conditions for the formation of industrial cluster, the industrial cluster is a system formed by coupling of inter-industry linkage and inter-enterprise relationship essentially. Coupling is a term in physics originally, which has been extensively applied to the research on the geographic economy, regional economy and relevant management issues in recent years, referring to the dynamic linkage where the mutual influence, interdependence, and inter-coordination of two or more systems are carried out through the interaction [13]. At present, scholars often study the relationship between industrial cluster and urban development as well as industrial cluster and regional economic development using this method $[17,18,19]$.

For marine industrial cluster, at present, scholars have conducted empirical analysis of the promotion of marine industrial cluster to regional economic development and the formulation of marine policy [22,23,24],etc., in research methods, analytic processes such as Diamond Model Analytic Process [25, 26], Delphi Analytic Process [27] and Gini coefficient [28] are usually adopted to study industrial cluster. However, these analyses conduct researches from single perspective of either industry agglomeration or enterprise agglomeration. Different from these researches, this paper identified the marine industrial cluster, designed the evaluation index of coupling of development of marine industrial cluster and coastal cities from two perspectives of industrial linkage and spatial agglomeration, taking Shandong province, a typical coastal province in China, as an example, it studied the situation of the marine industrial cluster based on input-output data and data of marine enterprises of coastal cities, based on which it explored the coupling relationship between marine industrial cluster and coastal cities of Shandong province.

\section{RESEARCH METHOD AND INDEX SYSTEM}

\section{IDENTIFICATION METHOD OF INDUSTRIAL CLUSTER}

\section{Mechanism analysis of industrial cluster}

According to existing research, two factors form the industrial cluster: horizontal industrial linkage and vertical industrial linkage. The vertical industrial linkage refers to linkage among industries in industry chain (network), referring to the industry upstream and downstream linkage or linkage formed due to economic and technical reasons; the horizontal industrial linkage refers to cooperation competition linkage between enterprises and institutions in the same area. From the perspective of system theory, the system element of industrial cluster consists of two parts, i.e. industry $X_{1}$ and corresponding enterprise and institution $X_{2}$ , and the system structure of industrial cluster $S$ is a relatively stable linkage set entirety formed by system elements according to some rule. The mathematical description of industrial cluster system is as follows:

$$
S=\left\{X_{1}, X_{2} \mid X_{1} \times X_{1}, X_{2} \times X_{2}\right\}
$$

The industrial cluster consists of two important subsystems, i.e. industry linkage subsystem $S_{1}=X_{1} \times X_{1}$, and enterprise linkage subsystem $S_{2}=X_{2} \times X_{2}$. Essentially, the industrial cluster is a compound system coupled by industry linkage subsystem and enterprise linkage subsystem, where, the industry linkage subsystem $S_{1}$ connecting industries in technical economy plays the basic and dominant role. It should be noted that both of vertical industrial linkage and horizontal industrial linkage should reach a certain scale and level to form strong linkage. Based on this, this paper proposed an identification method of strong linkage subsystem of industry and strong linkage subsystem of enterprise, based on which it determined the industrial cluster.

\section{Identification method of strong linkage subsystem of industry}

The industries in strong linkage subsystem of industry have the characteristics such as high linkage level, strong interaction with other industry, and wide radiation range, which are the basis and the key of the industrial cluster. Industrial linkage is the linkage in industry chain (network), input-output data are those can accurately study the interindustry relationship currently. It can reflect the relationship between input and output among industries in certain region and can obtain information relating to vertical linkage by processing input-output table. Zhao Bingxin et al. identified these industries as industries of vertical industrial cluster by filtering the weak linkage among industries and finding strong vertical linkage industrial cluster using graph and network method based on input-output data. Specific steps 
were as described below:

Step 1: Established industry network model $N$ based on input-output table following the modeling approach of Zhao Bingxin [29, 30].

Step 2: Calculated $k$-cores of industry network. Supposed industry network $N=(V, E), V$ was point set of network $N, E$ was frontier set of network $N, k$ was natural number, for any given $W \subseteq V$, network subfigure $H_{k}=(W, E \mid W)$ of $N$ was called $k$-cores of $N$, and met $d_{H_{k}}(v) \geq k$ only when $\forall v \in W$, moreover, $H_{k}$ was point pole big subfigure with such kind of characteristics.

Step 3: Defined sub-network $H_{k}$ with maximum core value as strong linkage subsystem of industry $S_{1}$, and industry set in $S_{1}$ was denoted as $V_{S 1}$.

\section{Identification method of strong linkage subsystem of enterprise}

The agglomeration situation of enterprise in some region can be identified by calculating concentration ratio of enterprise in some region using agglomeration index. Gini coefficient, Herfindahl index, and location quotient are often adopted in recent literature to calculate the concentration ratio of enterprise in some region [31-32]. This paper adopted the location quotient to calculate the concentration ratio of enterprises in some region to identify the strong linkage subsystem of enterprise. Location quotient (according to P. Haggett,) [33-35]:

$$
L Q_{i j}=\frac{x_{i j} / \sum_{j} x_{i j}}{\sum_{j} x_{i j} / \sum_{i} \sum_{j} x_{i j}}
$$

$i$ represented the $i$ th industry, $j$ represented the $j$ th industry, $x_{i j}$ represented the index of the $i$ th industry of the $j$ th region. Location quotient usually can be calculated using industry sales revenue, number of enterprises, number of employee of enterprises, etc. When $L Q_{i j}>1$, it indicated that the $i$ th industry of the $j$ th region had high concentration ratio of enterprise, supposed $V_{S 2}=\left\{i \mid L Q_{i j}>1\right\}$, and defined the system formed by $V_{S 2}$ as strong linkage subsystem of enterprise $S_{2}$.

Supposed $V_{c}$ was industry set of industrial cluster, industrial cluster was a compound system coupled by industry linkage subsystem and enterprise linkage subsystem, and defined $V_{c}=V_{S 1} \cap V_{S 2}$.

\section{COUPLING COORDINATION MODEL}

\section{Coupling degree model}

The coupling degree describes the degree of influence of multiple systems on each other, the bigger the coupling degree, the closer the linkage among systems, the higher the degree of influence. Before building the coupling degree model of marine industry cluster and urban development, you need to first define the evaluation function of marine industry cluster and evaluation function of urban development.

Defined the evaluation function of model of marine industry cluster as:

$$
U_{1}=\sum_{i=1}^{m} a_{i} x_{i}(i=1,2, \cdots, m)
$$

Where $a_{i}$ represented the weight of each index, and $x_{i}$ represented the standardized value of each index. Defined the evaluation function of urban development as:

$$
U_{2}=\sum_{j=1}^{n} b_{j} y_{j}(j=1,2, \cdots n)
$$

Where $b_{j}$ represented the weight of each index, and $y_{j}$ $x_{i}$ represented the standardized value of each index

This paper mainly studied the two systems of marine industry cluster and urban development, therefore, the coupling degree function was:

$$
C=\left\{\frac{U_{1} \times U_{2}}{\prod\left(U_{1}+U_{2}\right)}\right\}^{1 / 2}, \quad C \in(0,1)
$$

the bigger the coupling degree, the closer the linkage among systems, the higher the synergetic development coordination degree.

\section{Coupling coordination degree model}

The coupling degree function is unable to determine the influence of systems under study on each other on lower level or higher level, therefore, the coupling coordination degree function also needs to be calculated for study of synergetic development relationship among systems, i.e.:

$$
D=\sqrt{C \times T}, T=\alpha U_{1}+\beta U_{2}
$$

$D$ represented the coupling coordination degree, when $0<D \leq 0.4$, it indicated that it was low coordination; when $0.4<D \leq 0.5$, it indicated that it was moderate coordination; when $0.5<D \leq 0.8$, it indicated that it was high coordination; when $0.8<D \leq 1.0$, it indicated that it was extreme coordination; $T$ represented the comprehensive evaluation index of marine industry cluster and urban development. $\alpha$ and $\beta$ represented the undetermined coefficient, these two systems did not show full symmetry in terms of purpose in the process of synergetic development, this paper supposed $\alpha=0.4, \beta=0.6$

\section{INDEX SYSTEM AND DATA SOURCES}

\section{Index system}

In line with the principle of objectivity, scientificity and operability, this paper selected the index and established the index system of marine industry cluster and urban development. According to expert opinion, combining AHP method, this paper determined the weight of each evaluation index, see Table 1. 
Tab. 1 Evaluation Index System of Coupling of Marine Industry Cluster and Urban Development

\begin{tabular}{|c|c|c|c|}
\hline Target & System & Index & Weight \\
\hline \multirow{8}{*}{$\begin{array}{l}\text { Coupling of marine } \\
\text { industry cluster and } \\
\text { urban development }\end{array}$} & \multirow{3}{*}{$\begin{array}{c}\text { Marine industry } \\
\text { cluster }\end{array}$} & $\begin{array}{l}\text { Industrial location } \\
\text { quotient }\end{array}$ & 0.47 \\
\hline & & Market share & 0.29 \\
\hline & & \begin{tabular}{|l} 
Industrial \\
agglomeration \\
degree
\end{tabular} & 0.24 \\
\hline & \multirow{5}{*}{$\begin{array}{c}\text { Urban } \\
\text { development }\end{array}$} & $\begin{array}{l}\text { Gross regional } \\
\text { domestic product }\end{array}$ & 0.21 \\
\hline & & $\begin{array}{l}\text { Per capita gross } \\
\text { regional domestic } \\
\text { product }\end{array}$ & 0.11 \\
\hline & & $\begin{array}{l}\text { Aggregate income } \\
\text { of families }\end{array}$ & 0.14 \\
\hline & & $\begin{array}{l}\text { Household } \\
\text { consumption level }\end{array}$ & 0.18 \\
\hline & & $\begin{array}{l}\text { Urban population } \\
\text { density }\end{array}$ & 0.19 \\
\hline
\end{tabular}

\section{Data sources and processing}

The data used in this paper mainly came from Shandong Statistical Yearbook, China Statistical Yearbook, China Marine Statistical Yearbook, Input-Output Data and regional statistical yearbooks such as Qingdao Statistical yearbooks and Yantai Statistical Yearbook, and this paper also consulted economic reference data published periodically by national and local statistical bureau, data from the enterprise yearbook, and data from the industry analysis report and government report.

\section{EMPIRICAL ANALYSIS OF MARINE INDUSTRY CLUSTER OF SHANDONG PROVINCE AND ITS COUPLING WITH URBAN DEVELOPMENT}

Shandong province is a major marine province, bordering the Bohai Sea in the north and the Yellow Sea in the south. It is a province in China to develop marine industry earlier, in 2009, President Hu proposed "to make great efforts to develop marine economy, develop marine resource scientifically, cultivate marine competitive industries" during his inspection of Shandong province, in 2011, the Development Planning of Shandong Peninsula Blue Economic Zone was approved by the State Council, and developing Shandong's marine economy became an important part of national marine strategy. After several years of development, Shandong's marine industries have formed a complete industry system, and some of the industries present a clustering development trend, and these industries boost the local development even the economic development of the whole Shandong province, and are important measures for non-balanced development of Shandong province. Based on this, this paper selected Shandong province as a research object to first study the situation of marine industry cluster of Shandong province, based on which it further studied the coupling coordination situation of marine industry cluster of the coastal city of Shandong province with its urban development.

\section{ANALYSIS OF MARINE INDUSTRY CLUSTER OF SHANDONG PROVINCE}

According to input-output table of Shandong province [1] developed by Zhao Bingxin (2015), this paper determined the strong linkage subsystem of marine industry of Shandong province, and calculated the location quotient of marine industry of Shandong province based on number of enterprises to determine the strong linkage subsystem of enterprise. This paper assigned weight for each industry with location quotient of industry as point weight, and the size of point represented the size of location quotient of industry. The calculation results are as shown in Fig. 1.

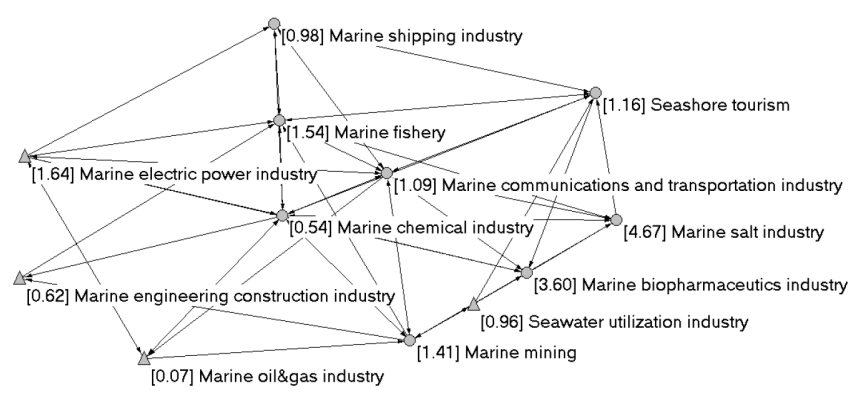

Notes: $\bigcirc$ Industry representing strong linkage subsystem of industry

Fig.1 Diagram of Marine Industry Cluster of Shandong Province

According to calculation, the strong linkage subsystem of industry included 7 marine industries, that is, $V_{S 1}$ includes industrial cluster, including marine fishery, marine salt industry, marine biopharmaceutics industry, marine communications and transportation industry, marine mining, marine chemical industry, and seashore tourism. The strong linkage subsystem of enterprise includes 7 marine industries, that is, $V_{S 2}$ includes industrial cluster, including marine fishery, marine salt industry, marine biopharmaceutics industry, marine communications and transportation industry, marine mining, marine electric power industry and seashore tourism By definition of industrial cluster made in this paper, $V_{c}=V_{S 1} \cap V_{S 2}$, it can thus be seen that 6 marine industries of Shandong province had reached the scale of industrial cluster, including marine fishery, marine salt industry, marine biopharmaceutics industry, marine communications and transportation industry, marine mining, and seashore tourism. According to cities where marine enterprise headquarter of Shandong province and branch office located, this paper determined the regional distribution of marine enterprise of coastal city of Shandong province, so as to determine the 
coastal city where 6 marine industries mainly agglomerated, see Table 2 .

Tab. 2 Distribution of Marine Industry Cluster of Coastal City of Shandong Province

\begin{tabular}{|c|c|c|c|c|c|}
\hline City & \multicolumn{5}{|c|}{ Cluster industry } \\
\hline 莺 & $\begin{array}{l}\text { Marine } \\
\text { fishery }\end{array}$ & $\begin{array}{l}\text { Marine } \\
\text { biopharmaceutics } \\
\text { industry }\end{array}$ & $\begin{array}{l}\text { Seashore } \\
\text { tourism }\end{array}$ & $\begin{array}{l}\text { Marine } \\
\text { communications } \\
\text { and } \\
\text { transportation } \\
\text { industry }\end{array}$ & $\begin{array}{l}\text { Marine } \\
\text { mining }\end{array}$ \\
\hline $\begin{array}{l}\stackrel{\pi}{\pi} \\
\stackrel{0}{0} \\
\vdots \\
0\end{array}$ & $\begin{array}{l}\text { Marine } \\
\text { fishery }\end{array}$ & $\begin{array}{l}\text { Marine } \\
\text { biopharmaceutics } \\
\text { industry }\end{array}$ & $\begin{array}{l}\text { Seashore } \\
\text { tourism }\end{array}$ & $\begin{array}{l}\text { Marine } \\
\text { communication } \\
\text { and Transporta } \\
\text { industry }\end{array}$ & \\
\hline$\frac{\bar{\pi}}{3}$ & $\begin{array}{l}\text { Marine } \\
\text { fishery }\end{array}$ & $\begin{array}{l}\text { Marine } \\
\text { communications } \\
\text { and } \\
\text { transportation } \\
\text { industry }\end{array}$ & Seashore & tourism & \\
\hline$\frac{\mathbb{Z}}{\stackrel{\mathbb{Z}}{N}}$ & $\begin{array}{l}\text { Marine } \\
\text { fishery }\end{array}$ & $\begin{array}{l}\text { Marine } \\
\text { communications } \\
\text { and } \\
\text { transportation } \\
\text { industry } \\
\end{array}$ & Seashore & tourism & \\
\hline $\begin{array}{l}.0 \\
.0 \\
00 \\
\tilde{0} \\
0\end{array}$ & \multicolumn{5}{|c|}{ Marine fishery } \\
\hline $\begin{array}{l}\text { 节 } \\
\text { 节 } \\
3\end{array}$ & \multicolumn{5}{|c|}{ Marine fishery } \\
\hline 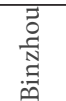 & \multicolumn{5}{|c|}{ Marine salt industry } \\
\hline
\end{tabular}

As seen in Table 2, marine fishery have formed an agglomeration in many coastal cities such as Yantai, Qingdao, Weihai, Rizhao, Dongying and Weifang; marine communications and transportation industry mainly agglomerate in Qingdao, Yantai, Rizhao and Weihai, these cities have China's important coastal harbor and large-scale marine transportation enterprise, too; with the development of tourism in recent years, seashore tourism has formed in coastal cities of Shandong province such as Qingdao, Yantai, Weihai and Rizhao. Different from marine fishery, marine communications and transportation industry and seashore tourism, marine salt industry enterprises, marine biopharmaceutics industry enterprises and marine mining enterprises showed an uneven distribution in coastal cities, marine biopharmaceutics industry enterprises mainly agglomerate in Yantai and Qingdao, forming industrial cluster; marine salt industry enterprises mainly agglomerate in Binzhou with many enterprises dominated by production of crude salt and salt chemical industry, e.g. Shandong Chengkou Salt Chemical Co. Ltd., Shandong Haiming Chemical Co., Ltd, etc.; marine mining enterprises mainly agglomerate in Yantai, forming industrial cluster, which has many marine mining enterprises, e.g. Shandong Gold Group Co Ltd., Penglai Jutal Offshore Engineering Heavy Industries Co. Ltd., etc., especially Shandong Gold Group Co Ltd. is now the only company engaging in undersea gold mining in China.

\section{EMPIRICAL ANALYSIS OF COUPLING OF MARINE INDUSTRY CLUSTER OF SHANDONG PROVINCE WITH ITS URBAN DEVELOPMENT}

This paper calculated the coupling coordination degree of marine industry cluster of 7 coastal cities of Shandong province with its urban development according to coupling coordination degree model, and the calculation results are as shown in Table 3.

Tab. 3 Value and Evaluation of Coupling Coordination Degree of Marine Industry Cluster of Shandong Province with Urban Development

\begin{tabular}{|c|c|c|c|c|c|c|}
\hline City & U1 & U2 & C & T & D & $\begin{array}{c}\text { Coupling } \\
\text { coordination } \\
\text { degree }\end{array}$ \\
\hline Qingdao & 0.69 & 0.78 & 0.61 & 0.75 & 0.67 & $\begin{array}{c}\text { High coupling } \\
\text { coordination } \\
\text { degree }\end{array}$ \\
\hline Yantai & 0.72 & 0.59 & 0.57 & 0.64 & 0.61 & $\begin{array}{c}\text { High coupling } \\
\text { coordination } \\
\text { degree }\end{array}$ \\
\hline Weihai & 0.39 & 0.45 & 0.46 & 0.43 & 0.44 & $\begin{array}{c}\text { Moderate coupling } \\
\text { coordination } \\
\text { degree }\end{array}$ \\
\hline Weifang & 0.21 & 0.34 & 0.36 & 0.29 & 0.32 & $\begin{array}{c}\text { Low coupling } \\
\text { coordination } \\
\text { degree }\end{array}$ \\
\hline Binzhou & 0.35 & 0.31 & 0.41 & 0.33 & 0.37 & $\begin{array}{c}\text { Low coupling } \\
\text { coordination } \\
\text { degree }\end{array}$ \\
\hline Rizhao & 0.42 & 0.18 & 0.36 & 0.28 & 0.32 & $\begin{array}{c}\text { Low coupling } \\
\text { coordination } \\
\text { degree }\end{array}$ \\
\hline & 0.37 & 0.32 & 0.41 & 0.34 & 0.38 & $\begin{array}{c}\text { Low coupling } \\
\text { coordination } \\
\text { degree }\end{array}$ \\
\hline
\end{tabular}

As seen in Table 3, in the process of coupling coordination of marine industry cluster of Shandong province with urban development, only Qingdao and Yantai have high coupling coordination degree, Weihai has moderate coupling coordination degree. Other coastal cities of Shandong province such as Weifang, Dongying, Sunshine and Binzhou still have low coupling coordination degree.

Qingdao and Yantai are important coastal cities in China, important international trade ports and marine transportation junctions, playing an important role in the implementation of marine strategy 
by China. In recent years, relying on the abundant marine resources, based on marine fishery, with marine communications and seashore tourism as the developing priority, Qingdao and Yantai have gradually developed the marine biopharmaceutics industry and marine mining and emerging industry. In 2015, the share of GDP of marine economy of Qingdao has exceeded 20\%, and the contribution rate of marine cluster industries such as marine fishery, marine communications and transportation industry and seashore tourism to the urban development of Qingdao has been rising. Yantai is rich in marine mineral resources, and its gold reserve ranks first in China, and has the only company engaging in undersea gold mining in China. In addition, Qingdao and Yantai have many marine scientific research institutions, especially Qingdao is home to $30 \%$ of marine scientific research institutions, and 50\% of high-level marine scientific research personnel of China, all of which promote the marine industry cluster and urban economy.

Weihai is located at the easternmost edge of Jiaodong Peninsular, as an important harbor in the northern China, it is open to navigation all the year round. Meanwhile, Weihai is rich in marine fishery resources, and the largest aquatic products processing base in China. In recent years, seashore tourism has also become a new growth point of Weihai's economy. However, other marine industries develop slowly in Weihai and have not formed an industry agglomeration. Weifang, Dongying, Rizhao and Binzhou still have low coupling coordination degree in coupling coordination of marine industry cluster with urban development, most of the marine industries of these cities have not formed a cluster, and the marine industries also play a limited promoting role in the development of these cities.

\section{CONCLUSION}

Based on the analysis of the mutual influence and mutual promotion of marine industry cluster and urban development, this paper constructed the coupling development model of marine industry cluster and urban development, taking Shandong province as an example, analyzed the condition of marine industry cluster, and conducted an empirical research of coupling relationship between marine industry cluster and urban development of each coastal city of Shandong province using the coupling evaluation model calculation method, the results showed that:

(1) After recent years of development, the traditional marine industries had formed an industry cluster, and the emerging marine industries also began to present a clustering development trend, and these industries strongly boosted the urban development, however, most of the emerging marine industries had not formed an industrial cluster, thus playing a limited promoting role in the economic development. The traditional marine industries showed a rapid development, marine fishery, marine communications and transportation industry and seashore tourism had become important industries in the promotion of development of coastal cities, while the development of coastal cities further promoted the development of these marine industries. The emerging marine industries, such as marine mining, marine power and marine engineering construction industry, had low linkage level, and had not formed an industrial cluster, thus playing a limited promoting role in the urban development.

(2) The marine industry cluster and urban development had obvious coordination coupling development characteristics, presenting mutual promotion and mutual influence. The marine industry cluster promoted the urban development by means of innovation diffusion, employment promotion and increase of production value, while the urban development promoted the marine industry cluster by providing infrastructure and human resources.

(3) The number of marine industry cluster had an important influence on the urban development, and the marine industry cluster had become the new growth point of the urban development, the greater the number of marine industry cluster, the greater the driving force for the urban development. The marine industry cluster realized efficient use of resources and efficient drive of relevant industry by taking cluster advantage, thus achieving the regional economic growth and urban development.

\section{ACKNOWLEDGEMENTS}

This work was supported by the National Natural Science Foundation of China (No. 71371108).

\section{REFERENCES}

1. Zhao Bingxin, Xiao Wenwen, Tong Ren-Cheng, et al.. Research on the Connotation of Blue Economy and Its Linkage Structure Effect from the Perspective of Industrial Network--A Case of Shandong Province [J]. China Soft Science, 2015, 08: 135-147.

2. Wang Lili, Xiao Wenwen. Industry Linkage of Marine Industry and Marine-Land Industry Linkage DevelopmentBased on Input-Output Model [J]. Economic Geography, 2016, 01: 113-119.

3. Fernández-Macho J, Murillas A, Ansuategi A, et al. Measuring the maritime economy: Spain in the European Atlantic Arc[J]. Marine Policy, 2015, 60: 49-61.

4. Surís-Regueiro J C, Garza-Gil M D, Varela-Lafuente M M. Marine economy: A proposal for its definition in the European Union[J]. Marine Policy, 2013, 42: 111-124.

5. Salvador R. Maritime Clusters Evolution. The (not so) Strange Case of the Portuguese Maritime Cluster[J]. 
Journal of Maritime Research, 2014, 11(1): 53-59.

6. Morrissey K, O'Donoghue C. The potential for an Irish maritime transportation cluster: An input-output analysis [J]. Ocean \& coastal management, 2013, 71: 305-313.

7. Simões A, Soares C G, Salvador R. Multipliers, linkages and influence fields among the sectors of the Portuguese maritime cluster[J]. Maritime Technology and Engineering, 2014: 155 .

8. Hammervoll T, Halse L L, Engelseth P. The role of clusters in global maritime value networks[J]. International Journal of Physical Distribution \& Logistics Management, 2014, 44(1/2): 98-112.

9. Porter M. On Competition[M]. Harvard Business School Press, Boston, MA.,1998.

10. Roelandt T J A, Den Hertog P. Cluster analysis and clusterbased policy making in OECD countries: an introduction to the theme [J]. Boosting innovation: The cluster approach, 1999: 9-23.

11. Zhao B X, Du P L, Xiao W.W., et al. Industrial cluster core structure and its index system[J].System EngineeringTheory \& Practice, 2016, 36(1): 55-62

12. Titze M, Brachert M, Kubis A. The identification of regional industrial clusters using qualitative input-output analysis (QIOA) [J]. Regional Studies, 2011, 45(1): 89-102.

13. Zhou Hong. The Modern Chinese Dictionary [K]. Beijing: Guangming Daily Press, 2003.820 821.

14. Chen Yanyun, Qin Chuan. Interaction of Industrial Agglomeration and Economic Growth: Analysis of 14 City Groups [J]. Reform, 2012, 10: 38-43.

15. Shen Yufang, Liu Shuhua, Zhang Jing, Wang Nengzhou. The Correspondence among Industrial Cluster, City Group and Port Group on the Yangze Delata Area [J]. Economic Geography, 2010,05:778-783.

16. Sheng Yanchao, Zhong Zhiping. Study on the Coupling Coordinative Degree between Tourism Industry and Regional Economy-_A Case of Hunan Province [J]. Tourism Tribune, 2009,08:23-29.

17. Gao Nan, Ma Yaofeng, Zhang Chunhui. Space- time Coupling Differentiation of Tourism Industry of Chinese Silk Road Economic Belt and Regional Economy-Based on Panel Data of 9 Provinces in 1993-2012 [J]. Economic Management, 2015,09:111-120.

18. Chang Y C. Maritime clusters: What can be learnt from the South West of England[J]. Ocean \& Coastal
Management, 2011, 54(6): 488-494

19. Morrissey K, O’Donoghue C. The Irish marine economy and regional development[J]. Marine Policy, 2012, 36(2): 358-364.

20. Shinohara M. Maritime cluster of Japan: implications for the cluster formation policies[J]. Marit. Pol. Mgmt., 2010, 37(4): 377-399.

21. Ji Yujun, Liu LinJing. Analysis of the Linkage Relationship Between the Marine Industrial Cluster and the Coastal Regional Economic Development [J]. Marine Economy, 2013,03:1-7.

22. Doloreux D. Understanding regional innovation in the maritime industry: an empirical analysis[J]. International Journal of Innovation and Technology Management, 2006, 3(02): 189-207.

23. da Silva Monteiro J P V, Neto P A, Noronha M T. Understanding the ways and the dynamics of collaborative innovation processes: the case of the maritime cluster of the Algarve region (Portugal)[J]. Urban, Planning and Transport Research, 2014, 2(1): 247-264.

24. Wiese A, Brandt A, Thierstein A, et al. Revealing Relevant Proximities. Knowledge Networks in the Maritime Economy in a Spatial, Functional and Relational Perspective[J]. Raumforschung und Raumordnung, 2014, 72(4): 275-291.

25. Haezendonck E, Pison G, Rousseeuw P, et al. The competitive advantage of seaports[J]. International Journal of Maritime Economics, 2000, 2(2): 69-82.

26. Lee C B, Wan J, Shi W, et al. A cross-country study of competitiveness of the shipping industry[J]. Transport Policy, 2014, 35: 366-376.

27. Benito G R G, Berger E, De la Forest M, et al. A cluster analysis of the maritime sector in Norway[J]. International Journal of Transport Management, 2003, 1(4): 203-215.

28. Duranton G, Overman H G. Testing for localization using micro-geographic data[J]. The Review of Economic Studies, 2005, 72(4): 1077-1106.

29. Zhao Bingxin, Zhang Jianghua. Introduction to industry network theory [M]. Beijing: Economic Science Press, 2013

30. Zhao Bingxin, Yin Chong, Zhang Jianghua. A study on industry complex network and its modeling - On the example of. [J]. Economic Management, 2011, 7: 139-148. 
31. TORRE A. and RALLET A. Proximity and localization, Regional Studies2005, 39, 47-59.

32. OERLEMANS L. and MEEUS M. Do organizational and spatial proximity impact on firm performance?, Regional Studies 2005, 39, 89-104.

33. Haggett P, Cliff A.D., Locational Models [M].Londan: Edward Amold Ltd, 1977.

\section{CONTACT WITH THE AUTHOR}

Zhao Bingxin

$z b x @ s d u . e d u . c n$

School of Management

Shandong University

Jinan, Shandong, 250100

CHINA 